\title{
Households' Awareness, Attitudes and Practices Regarding Waste Cooking Oil Recycling in Petaling, Malaysia
}

\author{
Ibrahim Kabir ${ }^{1}$, MohdRusli Yacob ${ }^{2}$ and Alias Radam ${ }^{3}$ \\ ${ }^{I}$ (Faculty of Environmental Studies, University Putra Malaysia) \\ ${ }_{2}^{2}$ (Faculty of Environmental Studies, University Putra Malaysia) \\ ${ }_{3}^{3}$ (Faculty of Economics and Management, University Putra Malaysia)
}

\begin{abstract}
Cooking oil as an additive and medium of heat transfer plays a significant role in food preparation. Its attributes of providing food with good taste, colour and aroma gave it general acceptance among consumers. In recent years, huge amount of waste cooking oil (WCO) is generated and discharged into the environment in various countries of the world. This study examined empirically the households' awareness, attitudes and practices towards WCO recycling in Petaling District of Selangor State, Malaysia. Information on households' awareness, attitudes and practices regarding WCO reuse, recycling and disposal will give a hint on how to improve WCO management in order to reduce its associated environmental problems.The study was conducted based on 352 households, who were randomly interviewed face-to-face using structured questionnaires from February to June, 2013. The results indicated that the average WCO generated per household is $2.34 \mathrm{~kg} / \mathrm{month}$, and even though the households' awareness on the significance of WCO recycling were generally positive, only small portion of them are engaged into it. However the result of the logit regression revealed that awareness and attitude were the significant factors that influence households engagement into WCO recycling, there is need for intensifying efforts in creating more awareness on proper management of WCO. The researchers finally suggested ways on how to encourage WCO management among households in Petaling.
\end{abstract}

Keywords:Awareness, Attitude, Recycling,Waste Cooking Oil Management

\section{Introduction}

The current increase in human population and the extent at which consumers employ frying method in food preparations result in generating huge quantities of waste cooking oil (WCO) worldwide. Management of thesequantities of WCOhas recentlybecomea serious challenge in both developed and developing nations. The residue, which is also termed as Used Cooking Oil (UCO) or Recovered Vegetable Oil (RVO) literally means the remains of cooking oil obtained after using edible oils for food preparation [1,2].The higher the amounts of cooking oil used in food preparation, the more the chances of generating huge quantities of WCO [3].

Waste cooking oil has nowadays been reckoned among the liquid wasteswhich are generated daily from various sources comprising households, restaurants, catering establishments, and industrial kitchens [4].Due to the heat that is usually applied in frying processes, the physical and chemical features of the cooking oil change from their original form [1,2]. Waste cooking oil which is expected to be treated and managed in a manner that could not be detrimental to the human health and/or the environment, is being disposed of by consumers via sinks, waste bins, drainage systems, toilets, or directly to the immediate water bodies and lands. According to Chhetri [5], a greater quantity of WCO generated all over the world is being released into the environment. Kheang[6],also reported that around 50,000 tons of WCO generated from vegetable oils and/or animal fats are disposed of to the environment without proper treatment annually in Malaysia only. This act in the long run contributes to water and soil contamination, causes aquatic life distraction, sewer system blockages and overflow, increases water treatment and waste management cost, and consequently generates undesirableimpacts to the entire environmental system[7].

Dischargeof WCO into waters alter the oxygenation process and destroy the aquatic lives in the marine environment by forminga layer which covers the water surface and prevents oxygen dissolution. When the byproducts of oil degradation mixed with water they increase the chemical oxygen demand (COD) of the water and contaminate the water to be toxic. Consequently, the aquatic lives absorbed poisonous compounds from the polluted water and laterreturned to human through food chain [8].

Waste cooking oil emptied into drainage system results in several operation and maintenance problems to the system. The effect starts when the WCO solidifies and accumulates inside the drainage system to deny the sewage from flowing freely to the wastewater treatment plant or sewage chamber. Once sewage is blocked, it causes sewer backups and overflows into surrounding environment, which could result in potential environmental health hazards and an extra costs being required for clean-up efforts[5, 12, 13].

In terms of the health implication of WCO reuse, continuedheating and consumption of WCO was reported to be very dangerous to human health. By continuing reuse of WCO for food preparation one 
increasesthe risk of cardiovascular diseases, liver problem, and cancer. Whencooking oilis subjected to persistent heating, the concentration of the hydrocarbons in the oil increases and makes it unhealthy for human consumption $[2,8,9,10,11]$.

Waste cooking oil management aims at preventing the general environmental and health effects associated with its improper disposal and continuing consumption among consumers. It entails any legal and practical measures employed in ensuring that WCO is handled in a manner that has not in one way or the other affect the environmental and human welfare [4].Waste cooking oilcollection and recycling programme is among the most common practice in developed countries or regions like the EU, Japan, United States, and Taiwan [14].The programme involves collection and recycling of WCO for input in the productionof some valuable products which include production of soaps, energy by anaerobic digestion, thermal cracking, and recently the production of biodiesel; a fuel that can be used as a substitute to petrol-diesel.

Countries like China, Thailand and Singapore are also engaged into WCO collection and recycling for biodiesel [14, 15]. Malaysia, as the world second largest producer and first exporter of palm oil generates around 0.5 million tonnes of WCO annually [17].Hence, the country has the potential to sustain its recently established WCO collection and recycling centres at strategic places in various cities and towns. This study was conducted to determine the households' awareness, attitudes and practices about WCO collection and recycling in Petaling District of Selangor State, Malaysia.

\subsection{The Study Area}

\section{Materials and Methods}

Petaling is Selangor's most urbanised and populated district. It is geographically located at longitude $3^{\circ} 5^{\prime} 0^{\prime \prime} \mathrm{N}$, and latitude $101^{\circ} 35^{\prime} 0^{\prime \prime} \mathrm{E}$ andsituated in the middle of the Klang Valley adjacent to the Malaysia's Federal Capital, Kuala Lumpur. The district has the total households' population of 466, 862, occupies the land area of about $484.32 \mathrm{~km}^{2}$, and comprises three municipal councils namely: Majlis Bandaraya Shah Alam (MBSA), Majlis Bandaraya Petaling Jaya (MBPJ), and Majlis Perbandaran Subang Jaya(MPSJ) [18].Figure 1 shows theMap of Malaysia showing Petaling District in Selangor State.

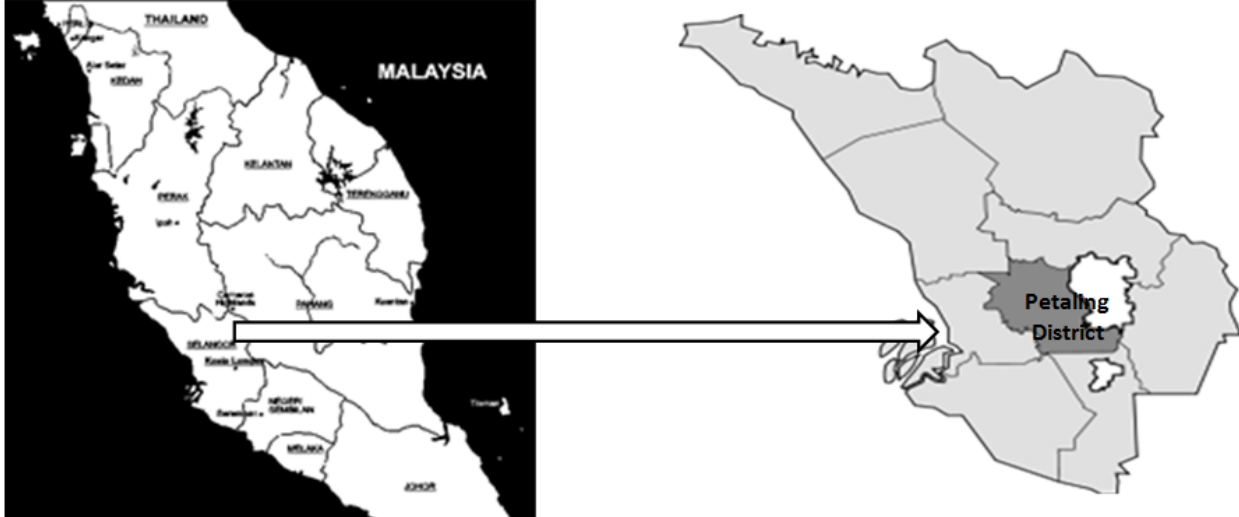

Figure 1: Map of Malaysia showing Petaling District in Selangor State

\subsection{Sampling and Data Collection}

From February to June of 2013, the researchers randomly collected data using structured questionnaire among 360 households in Petaling. The households of Petaling District were stratified and selected based on their respective Municipal Councils and the actual proportion of the total number of households in each of councils. In accordance with the households population differences among the municipal councils, the highest percentage of samples was drawn from Subang Jaya (41.0\%), followed by Petaling Jaya (36.0\%), then Shah Alam $(23.0 \%)$. The questionnaires were completed by the household heads or their representatives with the assistance of the survey team. The questionnaire used for this study was designed by the researchers in English and Malay languages. The contents of the questionnaire cover households' socio-demographic information, awareness on the significance of WCO recycling, attitude and practice regarding reuse and recycling of WCO. The households' socio-demographic information considered include age, gender, race, education, working status, number of persons per households, income and accommodation type. The households WCO management issues consideredincludethe quantityof cooking oil consumed and WCO generated, WCO reuse, recycling and disposal means. 
Households' Awareness, Attitudes and Practices Regarding Waste Cooking Oil Recycling in.....

\subsection{Data Analysis}

This study used Statistical Package for Social Science (SPSS) version 2.0 and NLOGIT 4.0 Limited Dependent Variable (LIMDEV) econometric software for data analysis. The analysis started with reliability test using the alpha model. Descriptive statistics was then used to explain households' socio-demographic background, practice regarding reuse, recycling and disposal of WCO, awareness on WCO recycling significance, and attitude towards WCO recycling.The logit model was used to determine the most significant factors that influenced the households' engagement into WCO recycling to biodiesel.

\section{Results And Discussions}

\subsection{Socio-demographic Information of the Households}

Of the 360 administered questionnaires, 352 responses were analysed and 8 were rejected due to the inconsistencies and households' refusal to answer some important questions. Table 1 shows socio-demographic information of the surveyed households. The result from the table revealed that the surveyed households' average age was 39 years oldand majority are female (66.5\%). Most of the respondents (22.7\%) live in four members per household, only $13.9 \%$ were in twos per households, and $58.5 \%$ are Malay which may be attributed to the fact that Malays are higher in population in Petaling. The respondents who completed Secondary School are higher in number in this survey $(47.2 \%)$ while the least percentage was for those who completed Primary School only (7.4\%). The surveyed households are mainly working with private sector (38.6\%), followed by self-employed (15.9\%), and only $7.4 \%$ were retired from service. The result also revealed that the average household monthly income of the surveyed households was RM3206, where $65.3 \%$ of them earned less than RM3000, and only $2.6 \%$ earned monthly income of above RM9000. Thus, the average households' monthly income of RM3206 is around the average income of half population of Malaysian citizens which is RM3000 [16].With regard to the accommodation type; majority (55.4\%) of the households live in terrace houses with only few of them (6.3\%)that live in bungalows.

Table 1: Socio-demographic Information of the Households

\begin{tabular}{|c|c|c|c|}
\hline Variable & Frequency & Percent & Mean \\
\hline AGE & & & 39 \\
\hline Less than 20 & 15 & 4.3 & \\
\hline $21-30$ & 102 & 29.0 & \\
\hline $31-40$ & 82 & 23.3 & \\
\hline $41-50$ & 84 & 23.9 & \\
\hline Above 50 & 69 & 19.6 & \\
\hline \multicolumn{4}{|l|}{ GENDER } \\
\hline Male & 118 & 33.5 & \\
\hline Female & 234 & 66.5 & \\
\hline \multicolumn{4}{|l|}{ TOTAL NUMBER IN HOUSEHOLD } \\
\hline Two & 49 & 13.9 & \\
\hline Three & 65 & 18.5 & \\
\hline Four & 80 & 22.7 & \\
\hline Five & 80 & 22.7 & \\
\hline More than five & 78 & 22.2 & \\
\hline \multicolumn{4}{|l|}{ RACE } \\
\hline Malay & 206 & 58.5 & \\
\hline Chinese & 71 & 20.2 & \\
\hline Indian & 56 & 15.9 & \\
\hline Others & 19 & 5.4 & \\
\hline \multicolumn{4}{|l|}{ EDUCATION } \\
\hline Primary School & 26 & 7.4 & \\
\hline Secondary School & 166 & 47.2 & \\
\hline College or Polytechnic & 62 & 17.6 & \\
\hline University & 98 & 27.8 & \\
\hline \multicolumn{4}{|l|}{ WORKING STATUS } \\
\hline Employment with Govemment & 65 & 18.5 & \\
\hline Employment with Private Sector & 136 & 38.6 & \\
\hline Unemployed & 37 & 10.5 & \\
\hline Self Employed & 56 & 15.9 & \\
\hline Retired & 26 & 7.4 & \\
\hline Others & 32 & 9.1 & \\
\hline MONTHLY GROSS HOUSEHOLD INCOME & & & RMB3206 \\
\hline Less than RM3000 & 230 & 65.3 & \\
\hline RM3001 - RM5000 & 71 & 20.2 & \\
\hline RM5001 - RM7000 & 31 & 8.8 & \\
\hline RM7001 - RM9000 & 11 & 3.1 & \\
\hline Above RM9000 & 9 & 2.6 & \\
\hline \multicolumn{4}{|l|}{ ACCOMODATION TYPE } \\
\hline Apartment & 101 & 28.7 & \\
\hline Condominium & 34 & 9.7 & \\
\hline Terrace House & 195 & 55.4 & \\
\hline Bungalow & 22 & 6.3 & \\
\hline
\end{tabular}

Source: Primary data (2013) 
Households'Awareness, Attitudes and Practices Regarding Waste Cooking Oil Recycling in.....

\subsection{Household's Practices regarding Reuse and Recycling of Waste Cooking Oil 3.2.1 WCO Consumption}

The results revealed that the average monthly consumption of cooking oil from the surveyed households was $4.68 \mathrm{~kg}$, where $86 \%$ of them consume $1-5 \mathrm{~kg}, 9 \%$ consumed $5.5-10 \mathrm{~kg}$, followed by $5 \%$ who consumed above $10 \mathrm{~kg}$ of cooking oil per month. Fig. 2summarised the quantities of cooking oil consumed per monthsper surveyed households. In the literature, as the quantity of cooking oil consumption increases, likewise the accumulation of the waste generated from cooking oil [3]. According to Zhang et al., [15], the rate of generation of WCO is about 50\% of cooking oil used, based on which we can estimate the average generated amount of WCO among households in Petaling is about $2.34 \mathrm{~kg} / \mathrm{month}$.

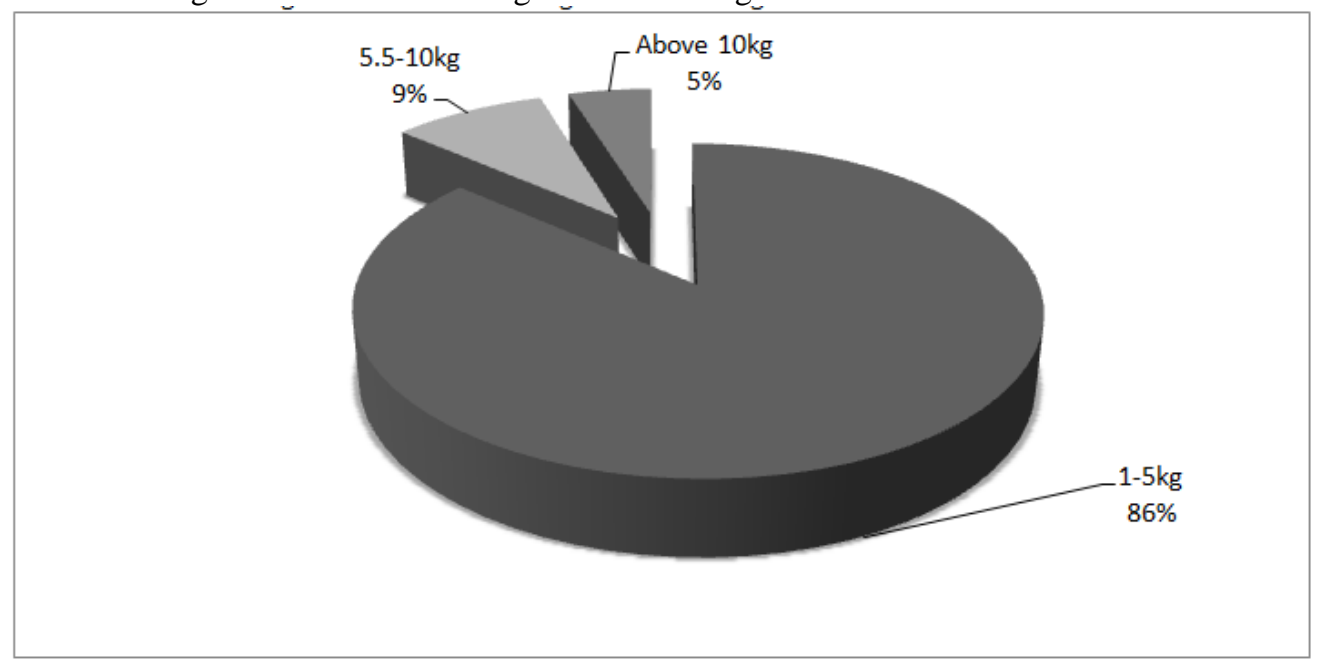

Figure 2: Quantity of WCO consumed per month $(\mathrm{kg})$.

\subsubsection{WCO Reuse, Recycling and Disposal Information}

- $\quad$ Times of reuse before disposal:In terms of cooking oil continuing reuse among households, it was found that $26.7 \%$ of them discard their WCO after one time usage, $47.2 \%$ after two times usage, $19.6 \%$ after three times usage, and only $6.5 \%$ discard the oil after 1-2 times plus top up. The continuing reuse of cooking oil in food preparation for two times or more was reported in the literatures as dangerous to health [9]. Fig. 3 shows the WCO reuse times among households in Petaling.

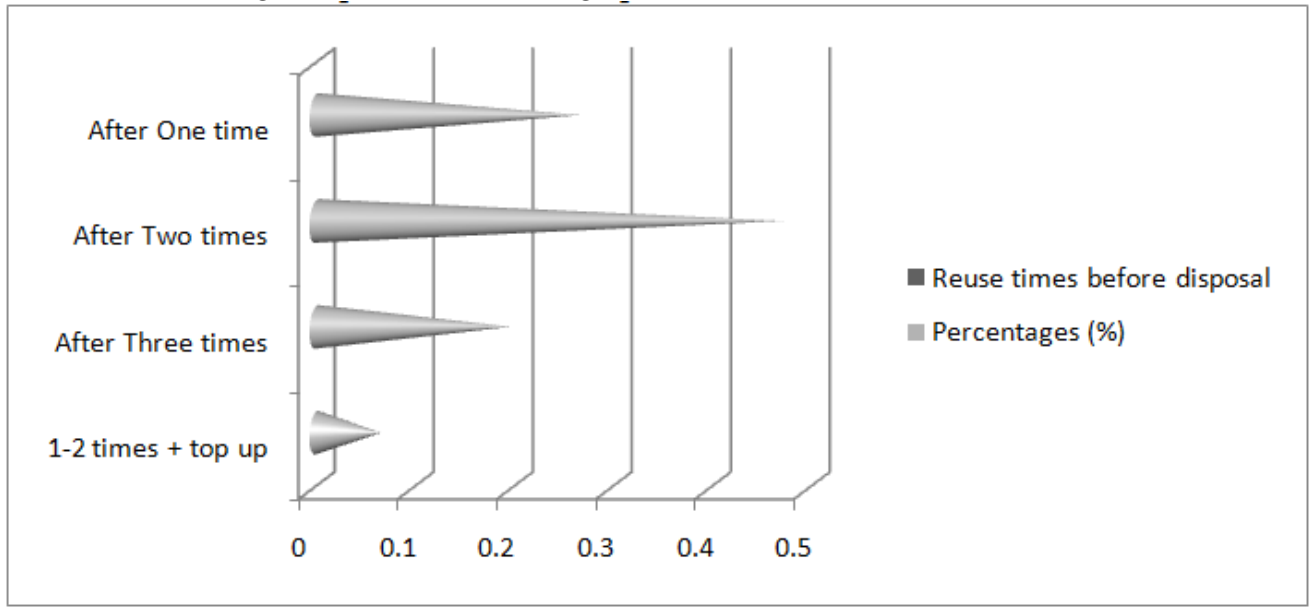

Figure 3: Times of WCO reuse before disposal

- Disposal Means: Amongst the four (4) disposal means optioned to the households,few(1.4\%) of them discard their WCO directly through soils and drainage systems, $21.9 \%$ discard their WCO to the waste bin, more than half of them (54.5\%) discard their WCO to house sinks, and 22.2\% discard their WCO to drains. Discharge of WCO to sinks, drains, or directly to the soil leads to water pollution and clogging of water pipes making the water treatment difficult and costly [7].Fig. 4 shows the WCO disposal means for households that do not recycle in Petaling. 


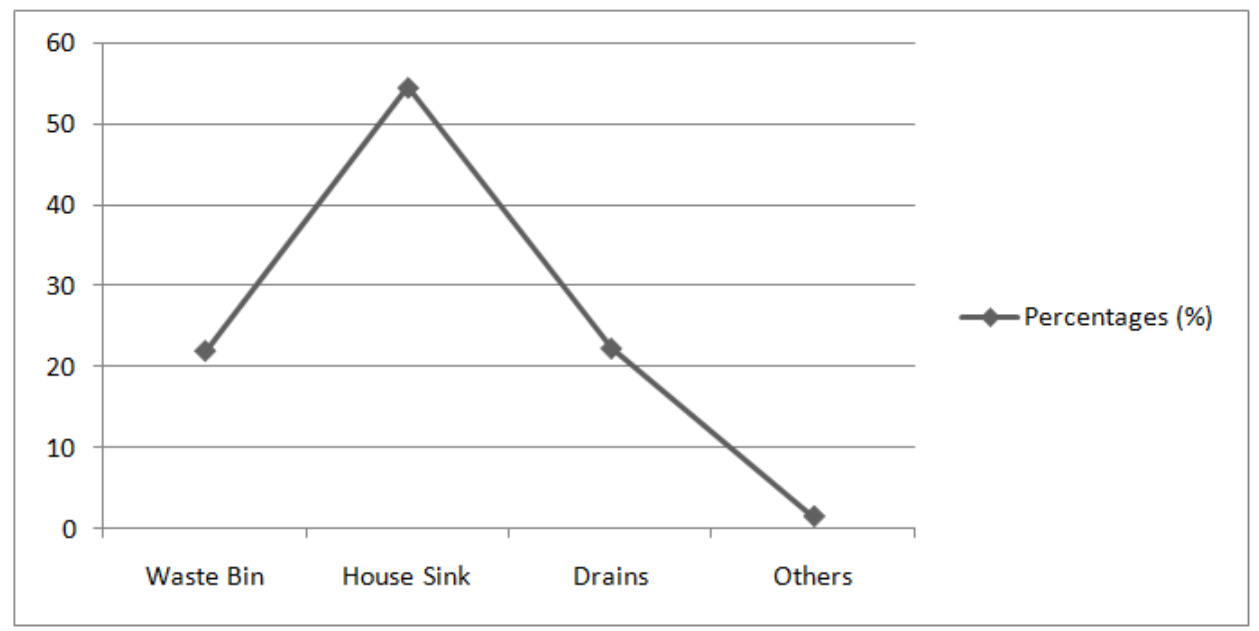

Figure 4: WCO disposal means

- WCO Recycling Status: This survey revealed that only $12 \%$ of the households recycle WCO, while $88 \%$ do not. This indicated that most WCO generated among households in Petaling is wasted and discharged in to the environment through different means. Thus, more awareness on the environmental effects of improper disposal of WCO is essential in the area. Fig. 5 captures the percentages of households that recycle WCO and those that do not.

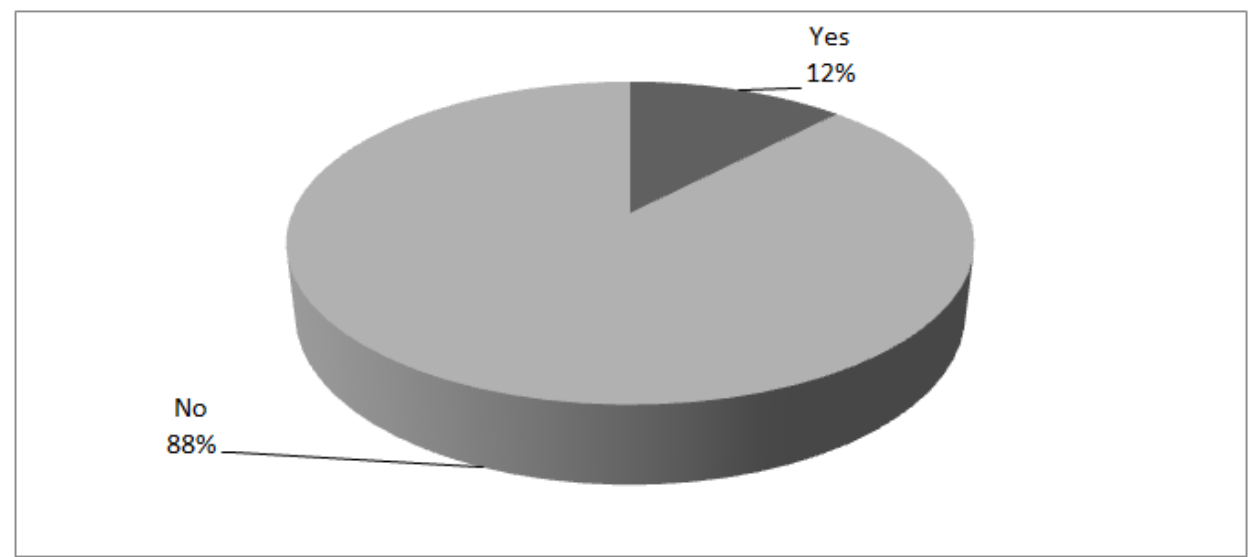

Figure 5: WCO recycling status

\subsection{Awareness on the significance of WCO recycling biodiesel}

The four recycling factors were found to be reliable at Cronbach's Alpha $(\alpha)=0.860$. Fig.6summarised the households' understanding on the significance of WCO recycling to biodiesel. From the figure, the two factors with the most significance are "WCO recycling to biodiesel will improve environmental quality"(mean value=3.98) and "WCO recycling is an important way to reduce pollution". WCO recycling is cheaper when compared with landfills maintenance and water treatment cost at long run (mean $=3.80)$. The results however indicated the households' agreement with all positive statements made on the environmental benefits of WCO management especially in dealing with environmental pollution by (mean $=3.92$ ) and improvement in the environmental quality (mean $=3.93$ ). The respondents also agreed that WCO recycling is cheaper when compared with landfills maintenance and water treatment cost at long run (mean value $=3.89$ ) and WCO recycling is a major way to increase biodiesel input (mean value $=3.82)$. However, these resultsindicated that the households have positive understanding on the importance of recycling WCO; only few (12.2\%)are engaged into it.Thus, by practice the surveyed households attached little importance to WCO recycling, and this may be attributed to the lack of broader understanding of the general environmental and health effects associated its improper disposal and continue consumption. 


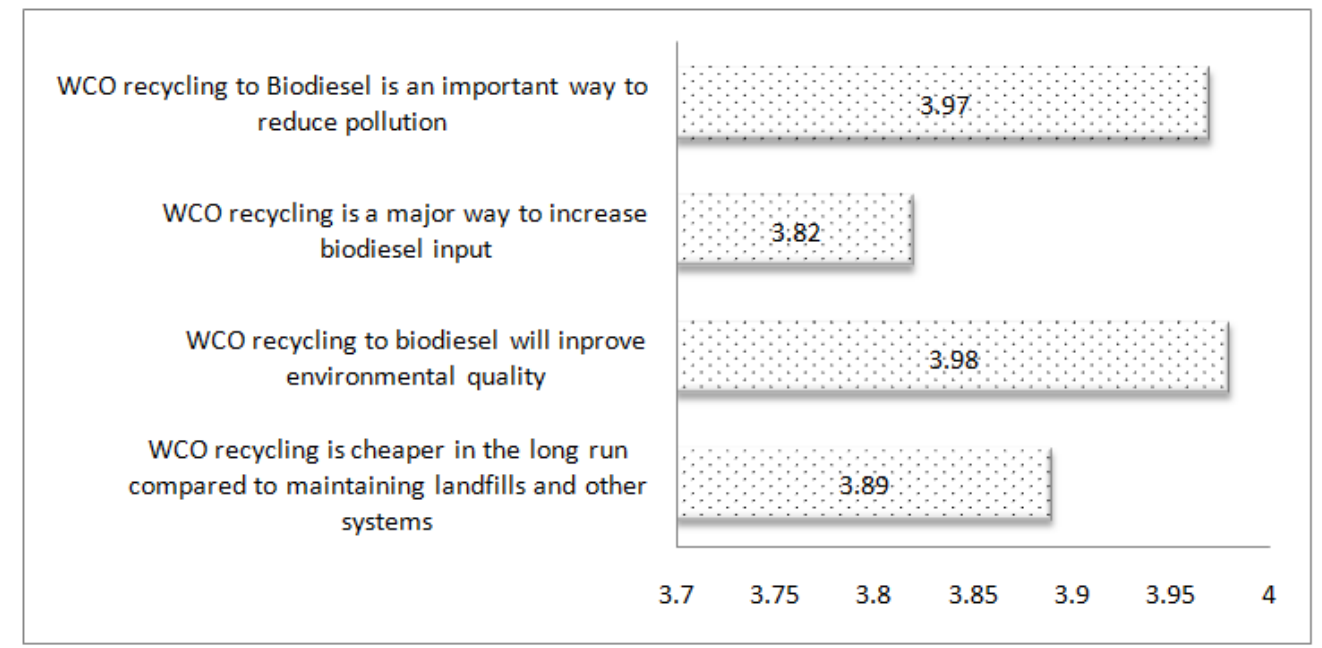

Figure 6: The surveyed households' responses on the significance of WCO recycling.

\subsection{Households attitudes towards WCO recycling biodiesel}

The four WCO recycling attitude factors were found to be reliable at Cronbach's Alpha $(\alpha)=0.709$. Fig. 7 summarised the households' attitudes towards WCO recycling biodiesel.From the figure, the two statements with highest percentages of households' level of agree and strongly agree are "Collection of WCO by contractors should be on time and efficient" agreed by $47.2 \%$ and strongly agreed by $25.9 \%$ and "Householdsrecycling of WCO is an easy task to do" was agreed by $41.8 \%$ and strongly agree by 31.3 respectively.

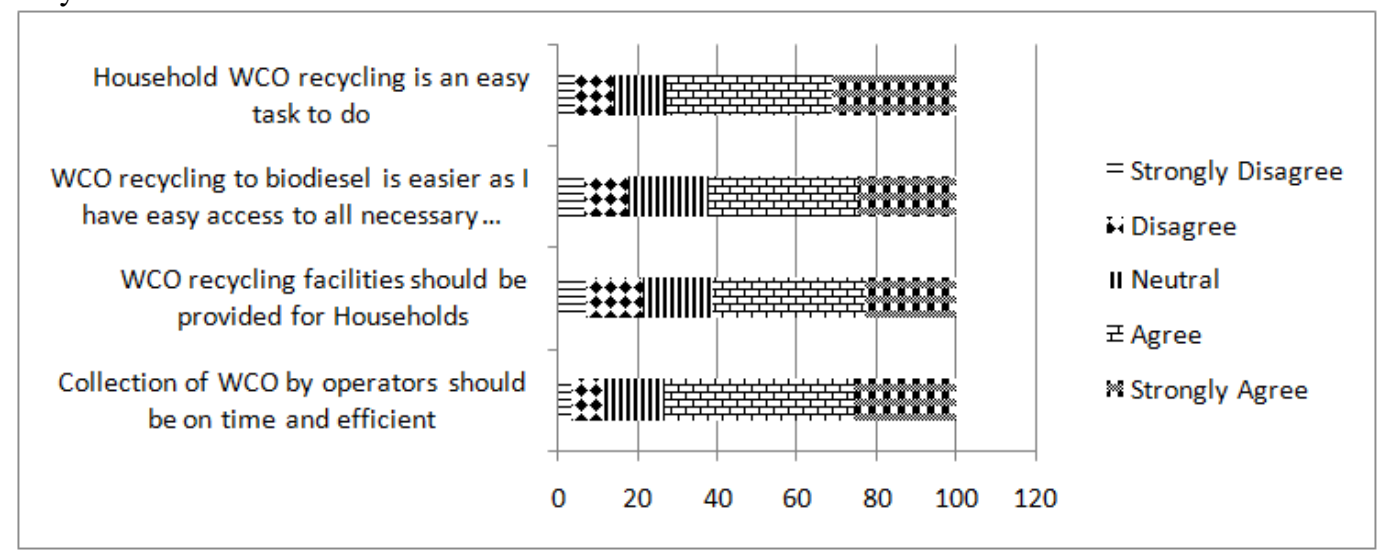

Figure 7:Households attitudes towards WCO recycling biodiesel

\subsection{Determinants of WCO recycling among households}

Logit model was used to determine the influence of awareness and attitudes on the households' engagement in WCO recycling activity. The results of the logit regression modelrevealed that awareness and attitudes are the significant factors that predict the households' engagement into WCO recycling. Hence, the positive coefficients of the independent variables can be inferred that household's engagement in recycling WCO to biodiesel is positively related to their awareness level and attitudes. Both the awareness and attitude are significant at $5 \%$ and $1 \%$ respectively. The households' level of awareness and attitude towards environmental issues play vital roles in their engagement into environmental activities [19]. Table 2, shows the logit regression results.

Table 2: Results of the logit regression model

\begin{tabular}{lllll}
\hline Variable & Coefficient & SE & Z & P-Value \\
\hline Constant & -15.9310799 & 2.18128689 & -7.304 & $0.0000^{*}$ \\
Awareness & 0.79237391 & 0.38789574 & 2.043 & $0.0411^{* *}$ \\
Attitude & 2.50435867 & 0.44330969 & 5.649 & $0.0000^{*}$ \\
McFadden's R & & & & \\
\hline
\end{tabular}

*Significant at $1 \%, * *$ Significant at $5 \%$ 


\section{Conclusion and Recommendations}

In an attempt to raise awareness and generate information that would be helpful in improving the WCO management among households, a survey was conducted to determine the households reuse of WCO, WCO recycling status, disposal means, awareness on WCO recycling significance and attitudestowards WCO recycling to biodiesel. The findings from this study revealed the necessity for rigorous public awareness campaign in order to encourage households to properly manage their WCO through recycling for biodiesel production. The awareness campaign should put more emphasis on the direct and indirect effects of improper disposal and continuing reuse of WCO in food preparation after usage of two or more times. To ensure the successful implementation of WCO recycling, government should widen the programmes not to cover only industries, restaurants, hotels and/or other lion's share users, but also every single household and individual person in the country would be required to play a role.A comparative study with different populations would assistin generalising our conclusions. Organisations responsible for managing WCO will benefit from additional empirical studies among communities in other parts of Malaysia.

\section{References}

[1]. Cvengroš, J., \&Cvengrošová, Z. (2004). Used frying oils and fats and their utilization in the production of methyl esters of higher fatty acids. Biomass and Bioenergy, 27(2), 173-181.

[2]. Azman, A., Shahrul, S. M., Chan, A., Noorhazliza, M. K., \& HMS, Q. (2012). Level of knowledge, attitude and practice of night market food outlet operators in Kuala Lumpur regarding the usage of repeatedly heated cooking oil. Medical Journal of Malaysia, 67(1), 91-101.

[3]. Phan, A. N., \&Phan, T. M. (2008). Biodiesel production from waste cooking oils. Fuel, 87(17), 3490-3496.

[4]. Castellanelli, C. A., \& de Mello, C. I. ANALYZES OF THE USED FRIED OIL UNDER ENVIRONMENTAL PERSPECTIVE AND ITS POSSIBILITIES FOR PRODUCTION OF BIODIESEL

[5]. Chhetri, A. B., Watts, K. C., \& Islam, M. R. (2008). Waste cooking oil as an alternate feedstock for biodiesel production. Energies, 1(1), 3-18.

[6]. Kheang, L. S., May, C. Y., Foon, C. S., \&Ngan, M. A. (2006). Recovery and conversion of palm olein-derived used frying oil to methyl esters for biodiesel. Journal of Oil Palm Research, 18, 247.

[7]. Chen, Y., Xiao, B., Chang, J., Fu, Y., Lv, P., \& Wang, X. (2009). Synthesis of biodiesel from waste cooking oil using immobilized lipase in fixed bed reactor. Energy conversion and management, 50(3), 668-673.

[8]. Kulkarni, M. G., \& Dalai, A. K. (2006). Waste cooking oil an economical source for biodiesel: a review. Industrial \& engineering chemistry research, 45(9), 2901-2913.

[9]. Jaarin, K., \&Kamisah, Y. (2012). Repeatedly Heated Vegetable Oils and Lipid Peroxidation. Open Acess, INTECH, 211-228.

[10]. Nawar, W. W. (1984). Chemical changes in lipids produced by thermal processing. Journal of chemical education, 61(4), 299.

[11]. Hanisah K., K. S., Tajul A. Y. (2013). The Management of Waste Cooking Oil: A Preliminary Survey. Health and the Environment Journal, 13.

[12]. Schiffman, S. S., Walker, J. M., Dalton, P., Lorig, T. S., Raymer, J. H., Shusterman, D., \& Williams, C. M. (2000). Potential health effects of odor from animal operations, wastewater treatment, and recycling of byproducts. Journal of Agromedicine, 7(1), 7-81.

[13]. Carlos A. Guerrero F., A. G.-R. a. F. E. S. (2011). Biodiesel Production from Waste Cooking Oil. National University of Columbia

[14]. Jaruyanon, P., \&Wongsapai, W. (2000). Biodiesel Technology and Management From Used Cooking Oil in Thailand Rural Areas. downloaded from the internet. June.

[15]. Zhang, Y., Bao, X., Ren, G., Cai, X., \& Li, J. (2012). Analysing the status, obstacles and recommendations for WCOs of restaurants as biodiesel feedstocks in China from supply chain'perspectives. Resources, Conservation and Recycling, 60, 20-37.

[16]. Afroz, R., \&Masud, M. M. (2011). Using a contingent valuation approach for improved solid waste management facility: Evidence from Kuala Lumpur, Malaysia. Waste management, 31(4), 800-808.

[17]. Yaakob, Z., Mohammad, M., Alherbawi, M., Alam, Z., \&Sopian, K. (2013). Overview of the production of biodiesel from waste cooking oil. Renewable and Sustainable Energy Reviews, 18, 184-193.

[18]. Department of Statistics Census Data, 2010.

[19]. Abdul-Muhmin, A. G. (2007). Explaining consumers' willingness to be environmentally friendly. International Journal of Consumer Studies, 31(3), 237-247. 